\title{
PENGARUH VISUAL MERCHANDISING TERHADAP IMPULSE BUYING MELALUI POSITIVE EMOTION PADA ZARA SURABAYA
}

\author{
Jovita Guntara Sudarsono \\ Praktisi pemasaran di Surabaya \\ E-mail: jo_guntara@gmail.com
}

\begin{abstract}
Abstrak: Perkembangan ritel di Indonesia terus meningkat. Selain itu, permintaan masyarakat Indonesia atas pakaian juga terus bertambah. Hal ini menjadikan Indonesia sebagai pasar potensial bagi ritel luar negeri dan turut bersaing di pasar ritel di Indonesia. Oleh karena itu, pihak manajemen harus memahami perilaku konsumen yang sering terjadi pada gerai ritel yaitu impulse buying. Impulse buying bahkan mampu menguasai $65 \%$ jumlah total pembelian dalam sebuah toko, sehingga sangat penting untuk mengetahui variabel-variabel yang mampu mempengaruhi impulse buying. Dengan demikian maka penelitian ini bertujuan untuk menganalisa pengaruh dari Visual Merchandising (window display, mannequin display, promotional signage, floor merchandising) terhadap Impulse Buying (affective dan cognitive) melalui Positive Emotion (pleasure, arousal, dominance) pada Zara Surabaya. Penelitian ini akan dilaksanakan dengan menyebarkan kuisioner kepada 100 responden konsumen Zara Surabaya dengan program smart-PLS melalui metode path analysis. Menurut hasil penelitian yang telah dilakukan oleh peneliti maka variabel visual merchandising memiliki hubungan, namun tidak signifikan terhadap impulse buying. Sedangkan variabel visual merchandising berhubungan secara signifikan terhadap positive emotion. Begitu pula dengan hubungan variabel positive emotion dengan impulse buying.
\end{abstract}

Kata kunci: Visual merchandising; positive emotion, impulse buying, window display; mannequin display; promotional signage; floor merchandising; affective; cognitive; pleasure; arousal; dominance.

\begin{abstract}
Retail developments in Indonesia continues to increase. In addition, demand for Indonesian society on clothing is also growing. This makes Indonesia as a potential market for foreign retail and also competing in the retail market in Indonesia. Therefore, management must understand consumer behavior that often occurs in retail outlets is impulse buying. Impulse buying even able to control $65 \%$ of the total purchases in a store, so it is important to know the variables that can affect impulse buying. Thus, this study aims to analyze the influence of Visual Merchandising (window displays, mannequins display, promotional signage, merchandising floor) on the Impulse Buying (affective and cognitive) through Positive Emotion (pleasure, arousal, dominance) in Surabaya Zara. This study will be conducted by distributing questionnaires to 100 respondents Zara Surabaya consumers with smart-PLS program through path analysis method. According to research conducted by the researchers then visual merchandising variables have a relationship, but not significant to impulse buying. While the visual merchandising variables significantly related to positive emotion. Similarly, the variable positive emotion relationship with impulse buying.
\end{abstract}

Keywords: Visual merchandising; positive emotion; impulse buying; window display; mannequin display; promotional signage; floor merchandising; affective; cognitive; pleasure; arousal; dominance.

\section{PENDAHULUAN}

Pertumbuhan bisnis ritel di Indonesia terus mengalami peningkatan setiap tahunnya dan diperkirakan akan terus bertumbuh selama beberapa tahun yang akan mendatang.

Omzet ritel modern nasional pada 2014 diperkirakan tumbuh $10 \%$ dan nilai penjualan ritel modern 2014 mencapai Rp162,8 triliun (Frontier Consulting Group, 2014). Selain itu, dengan dibukanya pintu masuk bagi para peritel asing sebagaimana Keputusan Presiden No. 118/2000 yang telah mengeluarkan bisnis ritel dari negative list bagi penanaman modal asing (PMA), ritel asing mulai marak masuk ke Indonesia (Marketing.co.id, 03/01/2013).

Jumlah brand fesyen bertaraf internasional semakin bertambah karena Indonesia dinilai sebagai pasar yang potensial. Hal tersebut dapat ditinjau melalui prediksi pengeluaran masyarakat Indonesia dalam bidang apparel yang menempati posisi keempat tertinggi (Oberman, 2012)

Surabaya merupakan kota terbesar kedua di Indonesia setelah ibukota Jakarta yang semakin diperhitungkan oleh pebisnis ritel nasional maupun internasional, seiring pertumbuhan ekonomi yang berada pada posisi 7 persen hingga $7.5 \%$ selama tiga tahun terakhir (Kompas.com, 01/07/2015). Namanama besar dalam jaringan ritel internasional lebih antusias melakukan ekspansi di pasar Surabaya. Hal ini ditandai dengan merek-merek menengah semacam Zara yang mulai beroperasi tahun lalu di pusat belanja Surabaya Timur, yang kemudian disusul oleh Stradivarius, Cotton On, dan New Look. Selain itu, peritel asal Swedia dan Jepang yakni H\&M dan Uniqlo juga telah membuat komitmen dengan dua pusat belanja Surabaya lainnya yang saat ini masih dalam tahap 
pengembangan (Kompas.com, 01/07/2015). Langkah tersebut diikuti merek premium seperti Louis Vuitton, Burberry, Balenciaga, Yves Saint Laurent, Hugo Boss, Michael Kors, Toni Dress, Rolex, Tag Heuer dan Victoria's Secret. Pasokan tersebut akan bertambah sebanyak 31\% hingga 2018 mendatang. (Kompas.com, 01/07/2015).

Dengan bertambahnya jumlah ritel fesyen, maka pihak manajemen harus mengerti kebutuhan dan keinginan konsumen, serta membuat strategi-strategi yang handal untuk mempertahankan pelanggan dan menarik pelanggan baru. Perusahaan juga harus memahami perilaku konsumen dan salah satu perilaku konsumen yang sering terjadi pada gerai ritel adalah impulse buying.

Impulse buying merupakan keputusan pembelian yang dilakukan di dalam toko dengan tidak adanya pengakuan eksplisit akan kebutuhan atas pembelian tersebut sebelum masuk ke toko (Kollat \& Willett, 1967). Hal ini didukung oleh sebuah studi yang menemukan bahwa $65 \%$ keputusan pembelian supermarket dibuat di dalam toko dengan tidak direncanakan (Popai Consumer Buying Habits Study, 1977). Berdasarkan survey tersebut dapat dilihat bahwa impulse buying cenderung mendominasi pembelian yang dilakukan konsumen.

Terjadinya impulse buying dapat dikaitkan dengan in-store stimuli, yang bertindak sebagai pengingat dari kebutuhan belanja (Rook, 1987). Kehadiran ritel fesyen asing yang terus meningkat memaksa setiap toko fesyen untuk membuat pelanggan memasuki toko dan melakukan pembelian melalui pemanfaatan visual merchandising.

Visual merchandising merupakan teknik dalam mempresentasikan tampilan barang dagangan yang menarik eye-catching dan ditujukan pada pelanggan potensial (Jain et al., 2012). Tujuan utama pengecer ialah agar toko mereka menarik konsumen dengan membantu untuk menemukan barang yang diinginkan dan memotivasi untuk melakukan pembelian yang direncanakan, mendorong impulse buying, dan memberikan pengalaman belanja menyenangkan.

Faktor penting lainnya yang ikut berkontribusi dalam mempengaruhi impulse buying ialah positive emotion yang didefinisikan sebagai suasana hati yang memperngaruhi dan menentukan intensitas pengambilan keputusan konsumen (Rachmawati, 2009). Konsumen di kondisi emosional yang positif cenderung mengurangi kompleksitas dan waktu dalam pengambilan keputusan.

Zara merupakan salah satu ritel SPA (Specialty Store Retailer of Private Label Apparel) bertaraf internasional yang sukses, dimana menempati posisi penjualan di atas para pesaingnya (fastretailing.com, 18/12/2014).
Volume penjualan Zara Surabaya yang besar merupakan hasil dari pembelanjaan impulsif dari customer Zara. Berdasarkan pra-survey melalui wawancara pada 5 staf Zara Surabaya, mereka memberi gambaran bahwa 8 dari 10 customer Zara Surabaya merupakan impulse buyer. Pengunjung Zara dengan pembelian impulsif yang menguasai hingga $80 \%$ total penjualan ini seringkali masuk toko tanpa adanya rencana pembelian serta berakhir dengan membawa kantong belanja Zara yang berisi produk yang tidak mereka rencanakan sebelumnya.

Faktor utama yang memberikan kontribusi untuk kesuksesan Zara adalah presentasi tokonya. Setiap toko Zara identik dengan toko yang lain. Keseragaman ini dicapai melalui distribusi instruksi manual setiap dua minggu dan penegakan hukum secara tegas dari pihak visual merchandising di setiap toko Zara. Keunikan pada Zara ialah Zara tidak pernah memasang iklan pada media cetak, media suara, maupun baliho yang menghabiskan biaya besar. Zara memaksimalkan promosi melalui visual merchandising design pada gerainya karena hal ini dianggap lebih efektif dan memiliki biaya yang efisien (Cha, 2013). Berbeda dengan ritel pakaian lainnya yang menghabiskan 3\%-4\%dari penjualan untuk iklan, Zara hanya menghabiskan biaya iklan sebesar 0.3\% dari penjualan (Sood, 2013). Berdasarkan fenomena diatas, maka dilakukan penelitian mengenai pengaruh visual merchandising terhadap impulse buying melalui positive emotion pada Zara Surabaya.

\section{URAIAN PENELITIAN}

\section{Visual Merchandising}

Visual merchandising ialah teknik dalam mempresentasikan tampilan barang dagangan sangat menarik (eye-catching) dan ditujukan pada pelanggan potensial (Jain et al., 2012).

Proses tampilan visual merchandising bahkan seringkali disebut sebagai "silent salesperson" yang menyediakan informasi melalui media visual serta dengan menjual secara sugestif atau saran untuk menambahkan item ke pembelian konsumen (Bhalla \& Anuraag, 2010).

Terdapat beberapa dimensi-dimensi penting yang mendukung pengadaan visual merchandising dalam sebuah toko (Mehta \& Chugan, 2013), yaitu:

1) Window display

Window display adalah tampilan depan dari sebuah toko yang membantu pelanggan memutuskan apakah akan memasuki toko atau tidak (Mehta \& Chugan, 2013). 
2) Mannequin Display

Manekin merupakan salah satu alat komunikasi bagi ritel fashion yang digunakan untuk memamerkan atau menjelaskan tren fashion saat ini. (Bell \& Ternus, 2012).

3) Floor Merchandising

Floor merchandising merupakan penataan peralatan-peralatan yang mendukung pelaksanaan bisnis ritel dalam menciptakan ruang gerak bagi customer di dalam toko (Mehta \& Chugan, 2013).

4) Promotional Signage

Promotional Signage merupakan salah satu elemen dari visual merchandising yang membantu meningkatkan penjualan dengan memberikan informasi mengenai produk dan menyarankan item atau pembelian khusus (Levy \& Weitz, 2007).

\section{Positive Emotion}

Positive emotion merupakan suatu kecenderungan sifat afektif seseorang, yang muncul sebelum terbentuknya mood, dan merupakan hasil reaksi pada lingkungan yang mendukung ketertarikan pada produk ataupun adanya promosi penjualan yang menarik akan berpengaruh terhadap keputusan pembelian konsumen (Rachmawati, 2009).

Respon afektif terhadap pengaruh lingkungan yang mengarah pada perilaku pembelian konsumen dapat diuraikan menjadi 3 variabel (Mehrabian \& Russel, 1974), yaitu sebagai berikut:

\section{1) Pleasure}

Pleasure mengacu pada tingkat di mana individu merasakan baik, penuh kegembiraan, bahagia yang berkaitan dengan situasi tersebut.

2) Arousal

Arousal merupakan keadaan di mana seseorang merasakan siaga, digairahkan, atau situasi aktif.

3) Dominance

Dominance merupakan keadaan yang mengacu pada sejauh mana pelanggan merasa dikontrol atau bebas berbuat sesuatu dalam gerai (Donovan $\&$ Rositter, 1982).

\section{Impulse Buying}

Impulse buying merupakan keputusan pembelian yang dilakukan di dalam toko dengan tidak adanya pengakuan eksplisit akan kebutuhan atas pembelian tersebut sebelum masuk ke toko (Kollat \& Willett, 1967).

Pembelian impulsif biasanya timbul ketika konsumen berada di dalam toko dan dirangsang oleh stimuli eksternal (berupa produk yang dilihatnya), sehingga muncul keinginan dalam dirinya untuk segera membeli produk tersebut (Utami, 2010).

Keputusan pembelian impulsif seringkali lebih dipengaruhi oleh affective dan cognitive dalam diri seseorang (Coley \& Burgess, 2003). Keduanya dijelaskan lebih lanjut sebagai berikut:

1) Affective

Affective merupakan proses psikologis dalam diri seseorang yang merujuk kepada emosi, perasaan maupun suasana hati (mood) yang dibagi menjadi:

a. Irresistible Urge to Buy

Konsumen memiliki keinginan yang instan, terus menerus, memaksa, sehingga tidak dapat menahan dirinya untuk melakukan pembelian.

b. Positive Buying Emotion

Konsumen memiliki suasana hati positif yang berasal dari motivasinya untuk memuaskan diri melalui pembelian impulsif.

c. Mood Management

Suatu keadaan di mana muncul keinginan untuk mengubah atau menata perasaannya melalui pembelian impulsif.

2) Cognitive

Cognitive merupakan proses psikologis seseorang yang merujuk kepada struktur dan proses mental yang meliputi pemikiran, pemahaman dan penginterpretasian yang terdiri dari tiga komponen, yaitu:

a. Cognitive Deliberation

Konsumen merasakan adanya desakan untuk bertindak tanpa adanya pertimbangan mendalam atau memikirkan konsekuensi.

b. Unplanned Buying

Konsumen tidak memiliki rencana yang jelas dalam berbelanja.

c. Disregard for the future

Konsumen tidak menghiraukan masa depan saat melakukan pembelian impulsif.

\section{Kerangka Konseptual}

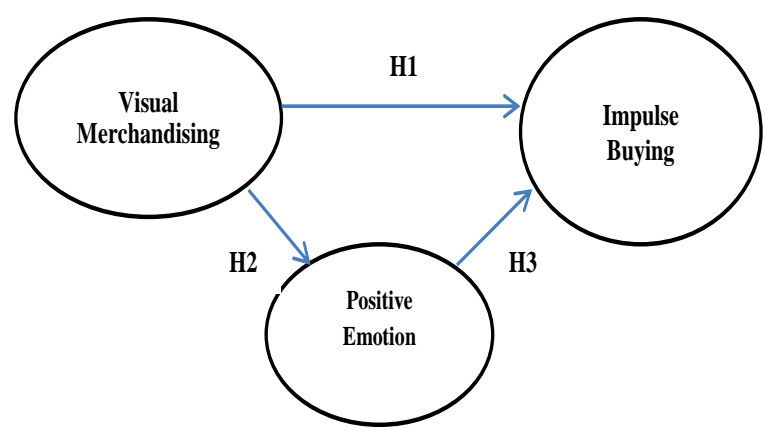

Gambar 1. Kerangka Konseptual 
Hipotesis

$\mathrm{H}_{1}$ : Visual Merchandising berpengaruh positif terhadap Impulse Buying.

$\mathrm{H}_{2}$ : Visual Merchandising berpengaruh positif terhadap Positive Emotion.

$\mathrm{H}_{3}$ : Positive Emotion berpengaruh positif terhadap Impulse Buying.

\section{METODE PENELITIAN}

\section{Jenis Penelitian}

Jenis penelitian yang digunakan untuk menunjukkan adanya hubungan antara visual merchandising, positive emotion dan impulse buying adalah penelitian deskriptif kausal.

Selain itu, penulis juga menggunakan pendekatan kuantitatif. Metode kuantitatif dilakukan dengan metode survey kuesioner terstruktur yang diberikan kepada sampel dari sebuah populasi dan didesain untuk memperoleh informasi yang spesifik dari responden (Malhotra, 2004).

\section{Populasi dan Sampel}

Populasi dari penelitian ini adalah masyarakat yang pernah berbelanja di Zara Surabaya. Dengan meneliti sebagian dari populasi diharapkan bahwa hasil yang didapat mampu menggambarkan populasi yang bersangkutan. Sampel yang diteliti oleh peneliti adalah 100 responden.

\section{Teknik Pengambilan Sampel}

Teknik pengambilan sampel yang akan digunakan dalam penelitian ini adalah teknik Non Probability Sampling yang mana kesempatan setiap individu untuk menjadi sampling tidak sama (Silalahi, 2003) dengan jenis purposive sampling, di mana peneliti melakukan penilaian untuk memilih anggota populasi yang dinilai paling tepat sesuai dengan kriteria tertentu (Simamora, 2004). Jadi pengambilan elemen-elemen yang dimasukkan dalam sampel dilakukan dengan sengaja, ditambahkan pula sampel harus representatif atau mewakili populasi.

Sampel yang ditentukan dalam penelitian ini adalah customer yang pernah berbelanja di Zara Surabaya dalam kurun waktu tiga bulan terakhir (Maret 2015-Mei 2015).

Penelitian ini menggunakan sampel sebanyak 100 responden, dengan berdasarkan pada pertimbangan tingkat keyakinan 0,95 dengan $\alpha 0,05$ dan kesalahan yang mungkin terjadi tidak lebih dari $10 \%$ sehingga pertimbangan ini dimasukkan ke rumus untuk menentukan sampel, sebagai berikut:
$n=\frac{Z^{2}}{4(M o e)^{2}} \quad n=\frac{(1,96)^{2}}{4(0.1)^{2}} \quad n=96,04$

n dibulatkan menjadi 100

dimana:

$\mathrm{Z}$ = Tingkat keyakinan yang dibutuhkan dalam penelitian sampel

Moe $=$ Margin of error , atau tingkat kesalahan maksimum yang dapat ditolerir

$\mathrm{n} \quad=$ Besarnya sampel

\section{Definisi Operasional Variabel}

Definisi operasional yang digunakan dalam penelitian ini terdiri dari 4 variabel, yaitu:

\section{Visual Merchandising $\left(\mathrm{x}_{1}\right)$}

Visual merchandising didefinisikan sebagai teknik mempresentasikan barang dagangan agar tampil lebih menarik. Dimensi dari visual merchandising adalah sebagai berikut:

- Window Display, adalah tampilan depan toko yang digunakan konsumen untuk mengobservasi toko seperti apakah Zara dan kategori yang dijual pada Zara sebagai bahan pertimbangan kunjungan, dengan indikator:

X1.1 Tampilan depan Zara yang menarik.

$\mathrm{X} 1.2$ Keputusan calon pelanggan memasuki toko Zara.

- Mannequin Display, adalah pengaturan merchandise yang sedang tren secara terampil manekin guna membuat tampilan produk lebih menarik dan memotivasi konsumen untuk membeli, dengan indikator:

X1.3 Media Promosi bagi produk-produk Zara.

X1.4 Menjelaskan tren fashion.

- Promotional Signage, adalah segala bentuk petunjuk ataupun informasi mengenai produk ataupun program khusus yang terdapat dalam Zara, dengan indikator:

X1.5 Informasi produk yang jelas.

X1.6 Keberadaan Promotional Signage yang tepat.

- Floor Merchandising, Adalah pengaturan barangbarang interior dan layout toko secara terampil guna menghasilkan ruang gerak yang nyaman pada gerai Zara, dengan indikator:

X1.7 Tata ruang (layout) gerai Zara.

X1.8 Ruang gerak (space) pada gerai Zara.

\section{Positive Emotion $\left(\mathrm{y}_{1}\right)$}

Positive emotion adalah suasana hati yang mempengaruhi dan menentukan intensitas pengambilan keputusan konsumen. Dimensi dari positive emotion adalah: 
- Pleasure, Adalah tingkatan dimana individu merasakan hal-hal baik dalam dirinya saat berbelanja di Zara, dengan indikator:

Y1.1 Perasaan positif saat Belanja.

Y1.2 Perasaan nyaman saat Belanja.

Y1.3 Semangat dalam Berbelanja.

- Arousal, Adalah gairah atau reaksi yang timbul dalam diri individu akibat adanya rangsangan terutama dari lingkungan yang tersedia di gerai Zara, dengan indikator:

Y1.4 Ketertarikan pada produk.

Y1.5 Kesediaan untuk membeli produk.

- Dominance, Adalah perasaan yang direspon konsumen saat mengendalikan atau dikendalikan oleh lingkungan, dengan indikator:

Y1.6 Kebebasan dalam Memilih.

Y1.7 Kebebasan memiliki Privasi.

Y1.8 Kebebasan dalam Bergerak.

\section{Impulse Buying $\left(\mathrm{y}_{2}\right)$}

Impulse Buying adalah persepsi yang ada di benak konsumen terhadap suatu merek atau perusahaan. Dimensi dari impulse buying adalah:

- Affective, Adalah elemen yang fokus pada kondisi emosional individu pada saat berbelanja di Zara, dengan indikator:

Y2.5 Keinginan Kuat untuk membeli yang

Muncul Tiba-Tiba.

Y2.6 Ketidakmampuan menahan keinginan.

Y2.7 Kepuasan Belanja.

Y2.8 Perasaan setelah berbelanja.

- Cognitive merupakan Adalah elemen yang fokus pada konflik yang terjadi dalam kegiatan mental pada saat berbelanja di Zara, dengan indikator:

Y2.1 Tidak Berpikir Panjang saat Berbelanja

Y2.2 Tidak Memikirkan Masa Depan

Y2.3 Adanya daftar belanja

Y2.4 Tidak Mau Ketinggalan Tren

\section{Teknik Analisa Data}

Peneliti menggunakan analisis PLS-SEM yang diterapkan didalam penelitian ini, yang mengacu pada struktur seperti yang dikemukakan oleh Ken Sewal Wright (1934), tahap-tahapnya adalah:

1. Dilakukan tahap evaluasi reliability yang terbagi menjadi dua tahap, yaitu evaluasi indicator reliability, dan evaluasi internal consistency reliability.

2. Kemudian dilakukan evaluasi validitas data dengan menggunakan convergent validity dan discriminant validity.

3. Dilakukan uji path coefficient dan coefficient of determination.

\section{ANALISA DAN PEMBAHASAN}

\section{Outer Model}

Convergent Validity

Tabel 1. Uji Convergent Validity

\begin{tabular}{lcc}
\hline \multicolumn{1}{c}{ Variabel } & AVE & Keterangan \\
\hline Impulse Buying & 0,799 & Valid \\
Positive Emotion & 0,718 & Valid \\
Visual Merchandising & 0,712 & Valid \\
\hline
\end{tabular}

Untuk memeriksa nilai convergent validity, diperlukan evaluasi Average Variance Extracted (AVE) setiap variabel laten. Nilai AVE harus lebih besar dari angka 0,5 untuk dapat memastikan bahwa tiap variabel memiliki parameter convergent validity yang layak digunakan. Tabel 1 mendemonstrasikan bahwa keseluruhan variabel yang digunakan pada penelitian ini memiliki convergent validity yang layak.

\section{Discriminant Validity}

Tabel 2. Uji Discriminant Validity

\begin{tabular}{lccc}
\hline & $\begin{array}{c}\text { Visual } \\
\text { Merchandising Emotion }\end{array}$ & $\begin{array}{c}\text { Positive } \\
\text { Euying }\end{array}$ \\
\hline Visual Merchandising & $\mathbf{0 , 8 9 4}$ & & \\
Positive Emotion & 0,751 & $\mathbf{0 , 8 4 7}$ & \\
Impulse Buying & 0,569 & 0,697 & $\mathbf{0 , 8 4 4}$ \\
\hline
\end{tabular}

Fornell dan Larcker (1981) menyarankan bahwa akar pangkat dua nilai AVE setiap latent variable harus lebih besar dari nilai korelasi terhadap variabel lainnya untuk memastikan discriminant validity.

Angka yang bercetak tebal di Tabel 2 didapatkan dari hasil akar pangkat dua nilai AVE pada latent variable, kemudian hasilnya dibandingkan dengan angka pada setiap latent variable lain yang berhubungan. Melalui Tabel ini dapat dijelaskan bahwa akar AVE visual merchandising $(0,894)$ lebih besar dari korelasi visual merchandising dengan positive emotion (0,751), dan impulse buying $(0,569)$. Sehingga variabel visual merchandising dapat dikatakan valid.

Akar AVE variabel positive emotion $(0,847)$ juga lebih besar dari korelasi positive emotion dengan visual merchandising $(0,751)$ dan impulse buying $(0,697)$. Maka kesimpulannya variabel positive emotion adalah valid.

Terakhir, akar AVE variabel impulse buying $(0,844)$ juga lebih besar dari korelasi impulse buying dengan visual merchandising $(0,569)$ dan positive emotion $(0,697)$. Dengan demikian, variabel impulse buying dapat dikatakan valid. 


\section{Composite Reliability}

Tabel 3. Uji Internal Consistency Reliable

\begin{tabular}{lcc}
\hline \multicolumn{1}{c}{ Variabel } & $\begin{array}{c}\text { Composite } \\
\text { Reliability }\end{array}$ & Keterangan \\
\hline Impulse Buying & 0,969 & Reliable \\
Positive Emotion & 0,953 & Reliable \\
Visual Merchandising & 0,952 & Reliable \\
\hline
\end{tabular}

Pengukuran internal consistency reliability untuk mengukur seberapa konsisten indikator tiaptiap variabel yang ada. Hasil penelitian Bagozzi \& Yi (1988) menyarankan penggunaan Composite Reliability untuk mengukur internal consistency reliability sebagai pengganti Cronbach's Alpha pada penelitian modern. Nilai composite reliability harus lebih dari 0,7 agar sebuah variabel dapat dikatakan reliable.

\section{Path Coefficient dan R-Square}

Evaluasi path coefficient digunakan untuk menunjukkan seberapa kuat efek atau pengaruh variabel independen kepada variabel dependen. Sedangkan coefficient determination digunakan untuk mengukur seberapa banyak variabel endogen dipengaruhi oleh variabel lainnya. Didalam marketing research, nilai R2 diatas 0,75 keatas dikategorikan substansial, 0,50 $-0,75$ artinya sedang, dan $0,25-0,50$ artinya lemah.

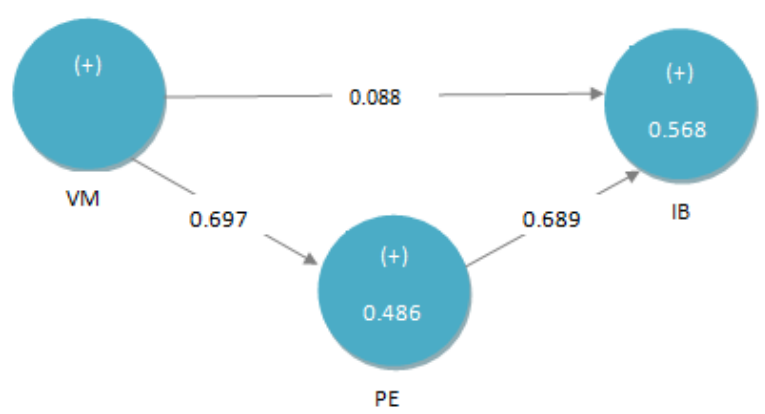

Gambar 2. Path Coefficient dan R-Square

Pada analisa path coefficient ini telah dibuktikan bahwa positive emotion merupakan variabel yang mampu memperkuat hubungan antara visual merchandising dan impulse buying.

Dari gambar diatas dapat dijelaskan bahwa nilai path coefficient terbesar ditunjukkan dari pengaruh visual merchandising terhadap positive emotion sebesar 0,697. Hubungan menuju impulse buying terkuat juga didapat ketika visual merchandising melewati positive emotion menuju impulse buying.

Pada hubungan visual merchandising terhadap impulse buying secara langsung memiliki path coefficient bernilai 0,088. Lalu ketika hubungan tersebut melalui variabel positive emotion terlebih dahulu, maka nilai dari path coefficient meningkat menjadi $0,480(=0,697 \times 0,689)$. Sehingga hal ini merupakan bukti bahwa positive emotion berperan sebagai variabel yang memperkuat hubungan antara visual merchandising dengan impulse buying.

Keseluruhan variabel dalam model ini memiliki path coefficient dengan angka yang positif. Hal ini menandakan bahwa apabila semakin besar nilai path coefficient pada satu variabel independen terhadap variabel dependen, maka semakin kuat juga pengaruh antara variabel independen terhadap variabel dependen tersebut.

Sementara itu, nilai coefficient of determination $\left(\mathrm{R}^{2}\right)$ yang pada gambar ditunjukkan pada angka di dalam lingkaran variabel positive emotion dan impulse buying. Hal ini menunjukkan bahwa variabel positive emotion dipengaruhi oleh variabel visual merchandising dengan nilai varian sebesar 0,486. Artinya sebanyak 51,4\% lainnya dijelaskan oleh variabel lain diluar penelitian. Sedangkan variabel impulse buying dipengaruhi oleh variabel visual merchandising dan positive emotion dengan nilai varian 0,568. Maka dari itu diketahui bahwa didalam penelitian ini impulse buying dipengaruhi sebesar 56,8\% dimana 43,2\% munculnya impulse buying dijelaskan oleh variabel-variabel lain diluar penelitian.

\section{T-Statistics dan Uji Hipotesis}

Nilai T-statistics diperoleh dari prosedur bootstrapping, dimana nilai ini digunakan untuk menarik kesimpulan pada uji hipotesis. Nilai T-statistics dengan level signifikansi 5\% menjelaskan bahwa inner model akan signifikan jika nilai T-statistics lebih besar dari 1,96.

Tabel 4. T-Statistics

\begin{tabular}{c|c|c|c|c|c}
\hline & $\begin{array}{c}\text { Original } \\
\text { Sample } \\
(\mathbf{O})\end{array}$ & $\begin{array}{c}\text { Sample } \\
\text { Mean } \\
(\mathbf{M})\end{array}$ & $\begin{array}{c}\text { Standard } \\
\text { Deviation } \\
\text { (STDEV) }\end{array}$ & $\begin{array}{c}\text { Standard } \\
\text { Error } \\
\text { (STERR) }\end{array}$ & $\begin{array}{c}\text { T } \\
\text { Statistics } \\
(\mathbf{| O / S T E} \\
\mathbf{R R})\end{array}$ \\
\hline $\begin{array}{c}\text { Visual } \\
\text { Merchandising } \\
\text { Impulse Buying }\end{array}$ & 0.088 & 0.084 & 0.116 & 0.116 & 0.755 \\
\hline $\begin{array}{c}\text { Visual } \\
\begin{array}{c}\text { Merchandising } \rightarrow \\
\text { Positive Emotion }\end{array}\end{array}$ & 0.697 & 0.687 & 0.086 & 0.086 & 8.142 \\
\hline $\begin{array}{c}\text { Positive Emotion } \rightarrow \\
\text { Impulse Buying }\end{array}$ & 0.689 & 0.691 & 0.089 & 0.089 & 7.759 \\
\hline
\end{tabular}

Dengan melihat Tabel 4, dapat diartikan bahwa nilai original sample $(\mathrm{O})$ adalah nilai path coefficient 
yang menunjukkan kekuatan pengaruh dari satu latent variable ke satu latent variable lainnya. Sedangkan nilai pada kolom sample mean (M) menunjukkan nilai tengah dari path coefficient. Sedangkan standard deviation (STDEV) dan standarderror (STDERR), menunjukkan nilai simpang dan error pada sample mean. Nilai $T$-statistics untuk melihat nilai $\mathrm{T}$ hitung yang akan digunakan untuk pengujian hipotesis.

T-statistics pada pengaruh visual merchandising terhadap impulse buying menunjukkan angka 0.755 , artinya bahwa visual merchandising tidak berpengaruh secara signifikan terhadap impulse buying. $T$ statistics pada pengaruh visual merchandising terhadap positive emotion menunjukkan angka 8.142, yang artinya bahwa visual merchandising berpengaruh signifikan terhadap positive emotion. T-statistics pada pengaruh positive emotion terhadap impulse buying menunjukkan 7.759, artinya positive emotion berpengaruh signifikan terhadap impulse buying. Berikut adalah hasil penarikan kesimpulan dari uji hipotesis.

Tabel 5. Uji Hipotesis

\begin{tabular}{c|c|c}
\hline Hipotesis & Keterangan & T-statistics \\
\hline H1 & $\begin{array}{c}\text { Tidak terdapat pengaruh yang signifikan } \\
\text { antara visual merchandising terhadap } \\
\text { impulse buying }\end{array}$ & 0.755 \\
\hline H2 & $\begin{array}{c}\text { Terdapat pengaruh yang signifikan antara } \\
\text { visual merchandising terhadap positive } \\
\text { emotion }\end{array}$ & 8.142 \\
\hline H3 & $\begin{array}{c}\text { Terdapat pengaruh yang signifikan antara } \\
\text { positive emotion terhadap impulse buying }\end{array}$ & 7.759 \\
\hline
\end{tabular}

\section{Pembahasan}

\section{Visual Merchandising terhadap Positive Emotion}

Melalui hasil penelitian ini, diketahui bahwa visual merchandising pada Zara Surabaya tidak mempunyai pengaruh langsung yang signifikan terhadap impulse buying pengunjung dengan nilai uji $\mathrm{T}$-statistics $<1,96$ yaitu sebesar 0,755 .

Visual merchandising terhadap impulse buying sendiri juga memiliki path coefficient yang kurang kuat yaitu 0,088 . Akan tetapi, memiliki path coefficient yang lebih tinggi ketika melalui positive emotion.

Hal ini tidak sesuai dengan penelitian yang dilakukan oleh Rook (1987), Han et al. (1991), dan Yanthi (2014) yang menyatakan bahwa ada hubungan langsung yang positif dan signifikan antara visual merchandising terhadap impulse buying. Hal ini merupakan suatu hal yang wajar, karena visual Merchandising pada sebuah toko tidak secara langsung membuat mereka melakukan impulse buying akan tetapi didukung juga oleh berbagai alasan, seperti ekonomi, kesenangan, kepuasan emosional dan faktor-faktor yang lain.

Selain itu, berdasarkan pengamatan yang dilakukan oleh penulis, hubungan pada visual merchandising dan impulse buying yang tidak signifikan dapat diakibatkan oleh faktor pengambilan sampel. Responden pada penelitian ini mayoritas ialah mahasiswa dengan persentase sebesar $61 \%$. Pemilihan sampel ini dikarenakan antara penduduk dunia 1,8 miliar remaja berusia 10-24 tahun, 1 miliar (61\%) tinggal di Asia, sehingga membuat segmen anak muda menjadi target pasar yang penting bagi para marketer (Nugent, 2006).

Konsumen usia 18-22 tahun adalah demografis yang paling khawatir tentang citra dan gaya hidup tren sehingga dipengaruhi oleh barang apa yang sedang tren dan menjadi perbincangan (Gluck, 2009). Mereka merupakan tipe konsumen yang mencari identitas diri. Mereka ingin terlihat seperti apa/seseorang yang mereka anggap baik. Oleh karena itu, peritel biasanya memasang manekin dan foto model dengan tubuh ideal. Hal ini dimanfaatkan karena secara tidak disadari, rangsangan seringkali melambangkan kepribadian dan identitas konsumen sendiri (Aaker, 1997). Rangsangan juga dapat mencerminkan citra diri yang diinginkan, atau mewujudkan tipe orang yang diidamkan untuk ditiru (Belk, Mayer, \& Bahn, 1982). Sehingga dalam kasus ini, variabel yang memberi pengaruh keputusan belanja yang lebih besar ialah brand personality. Hal ini dsebabkan individu menunjukkan minat dalam merek yang memiliki kemiripan dengan kepribadian mereka dan konsep atas diri mereka (Landon, 1974). Penelitian menunjukkan bahwa individu memilih merek yang memungkinkan mereka untuk meningkatkan citra diri mereka dan mendapatkan penerimaan sosial yang lebih besar (Belch, 1978). Brand Personality dipandang sebagai sarana bagi konsumen untuk mengekspresikan citra diri yang sebenarnya atau yang ideal menurut mereka (Keller \& Richey, 2006).

\section{Positive Emotion terhadap Impulse Buying}

Hasil penelitian menunjukkan bahwa visual merchandising berpengaruh signifikan terhadap positive emotion pelanggan. Pada hasil penelitian ini diketahui bahwa pengaruh secara signifikan tersebut merupakan hasil uji T-statistics dengan nilai 8.142, yaitu diatas 1.96. Sehingga diketahui bahwa visual 
merchandising mempengaruhi emosi positif yang ada di dalam diri konsumen.

Hal ini sesuai dengan teori yang menegaskan bahwa kesuksesan visual merchandising berpengaruh pada emosi konsumen (Hefer dan Cant, 2013). Perhatian konsumen tertuju pada aspek visual merchandising tertentu seperti warna dan juga ruang gerak dalam toko, sehingga menciptakan pengalaman belanja yang positif, dimana konsumen kadangkadang secara tidak sadar membeli produk terpengaruh oleh suasana hati saat ini.

Selain itu apabila dilihat dari nilai path coefficient, hubungan visual merchandising terhadap positive emotion berada pada nilai 0.429 . Hal tersebut menjelaskan bahwa terdapat pengaruh yang positif, dimana semakin baik Visual Merchanding maka semakin meningkat pula Positive Emotion.

\section{Positive Emotion terhadap Impulse Buying}

Dari hasil analisa penelitian ini dapat dibuktikan bahwa positive emotion memiliki pengaruh yang signifikan terhadap impulse buying dengan nilai $T$ statistics sebesar 7.759. Sehingga diketahui bahwa emosi positif mempengaruhi pembelian impulse konsumen.

Hal ini sejalan dengan teori yang diungkapkan Rook \& Gardner (1993) yang menegaskan bahwa apabila dibandingkan dengan emosi negatif, konsumen dengan emosi positif memungkinkan pembelian impuls yang lebih besar karena perasaan menjadi tidak dibatasi, adanya keinginan untuk menghargai diri mereka sendiri, dan tingkat energi yang lebih tinggi. Suasana hati yang senang yang dirasakan pengunjung Zara Surabaya tentunya akan memacu pembelian impulsif ketika berbelanja. Hal ini dikarenakan emosi positif yang dirasakan pada saat berbelanja akan mempengaruhi keputusan pembelian.

Selain itu positive emotion terhadap impulse buying memiliki path coefficient yang paling tinggi, yaitu 0,697 .

\section{KESIMPULAN}

Berdasarkan hasil penelitian mengenai analisa pengaruh visual merchandising terhadap impulse buying melalui positive emotion pada Zara Surabaya, maka diperoleh hasil sebagai berikut:

a. Terdapat pengaruh antara Visual Merchandising terhadap Impulse Buying secara langsung namun tidak signifikan. Hal ini diakibatkan penguasa pembelian pada bisnis ritel, termasuk di Zara Surabaya adalah anak muda. Bagi konsumen usia muda, visual merchandising bukanlah faktor utama yang mereka pertimbangkan saat berbelanja. Konsumen usia muda sangat peduli dengan identitas diri mereka. Sehingga sebuah brand yang baik dan mampu menyampaikan citra yang baik/diinginkan akan membuat mereka lebih tertarik untuk membeli dibandingkan dengan sebuah toko dengan tampilan yang menarik namun memiliki brand yang kurang baik atau tidak sesuai dengan citra diri mereka ataupun identitas diri yang mereka inginkan.

b. Visual Merchandising berpengaruh terhadap Positive Emotion, yang artinya ketika kualitas indera penglihatan konsumen dipuaskan oleh desain tampilan Zara serta merasa nyaman, maka pada saat itulah emosi positif pada konsumen timbul. Oleh karena itu, semakin baik perusahaan mendesain visual merchandising secara indah, maka emosi pengunjung akan semakin positif.

c. Terdapat pengaruh antara Positive Emotion terhadap Impulse Buying. Pada saat emosi konsumen dalam keadaan positif, maka lebih memungkinkan bagi mereka untuk melakukan pembelian impuls akan produk-produk Zara karena perasaan mereka menjadi tidak dibatasi, sehingga adanya keinginan untuk menghargai diri sendiri, dan tingkat energi pun meningkat. Sehingga dengan mengingkatnya emosi positif pada diri konsumen, maka kemungkinan mereka membeli secara impulsif pun semakin meningkat.

d. Jadi berdasarkan pembahasan yang telah diulas, maka dapat ditarik kesimpulan bahwa visual merchandising merupakan sebuah prediktor penting yang secara statistik berpengaruh signifikan terhadap positive emotion dan impulse buying. Hal ini ditunjukkan oleh sebagian besar konsumen yang setuju bahwa ia merasa tertarik untuk masuk ke dalam gerai Zara pada saat melihat desain depan toko serta merasa bersemangat pada saat berada dalam toko Zara.

Merujuk kepada hasil penelitian dan pembahasan, maka peneliti mengajukan beberapa saran bagi penelitian selanjutnya dengan menambahkan variabel bebas $(\mathrm{X})$ diluar variabel bebas yang digunakan dalam penelitian ini. Hal ini karena dimungkinkan ada variabel lain selain Visual Merchandising yang memiliki pengaruh terhadap Positive Emotion dan Impulse Buying pada sebuah fashion retail. Pemilihan variabel seperti brand personality akan membuat penjualan lebih optimal melalui target pasar anak muda yang memiliki jumlah yang besar serta terus mengalami pertumbuhan. Brand personality dapat memengaruhi pembelian impulsif melalui pemilihan seorang bintang yang sedang naik daun dan digemari 
oleh para anak muda sebagai brand ambassador yang menampilkan produk-produk Zara akan membuat konsumen ingin membeli yang memiliki pengaruh yang lebih signifikan dibandingkan dengan visual merchandising.

\section{DAFTAR PUSTAKA}

Aaker, J. (1997). Dimensions of brand personality. Journal of Marketing Research, 34, 347-357.

Bagozzi, R. P., \& Yi, Y. (1988). On the evaluation of structural equation models. Journal of the Academy of Marketing Science, 16(1), 74-94.

Belch, George E. (1978), Belief Systems and the Differential Role of the Self-Concept, Advances in Consumer Research, 5(1), pp. 320-25.

Belk, R. W., Mayer, R., \& Bahn, K. (1982). Developmental recognition of consumption symbolism. Journal of Consumer Research, 9, 4-17.

Bell, J. \& Ternus, K. (2012). Silent Selling 4th Ed. New York: Fairchild Publications.

Bhalla, S. \& Anuraag, S. (2010). Visual merchandising. New Delhi: McGraw Hill.

Cha Y. (2013). The Big 3: Fast Fashion (SPA) Brands and Strategies. Maeil Business Newspaper. Retrieved from: www.mk.co.kr

Coley A., \& Burgess B. (2003). Gender Differences in Cognitive and Affective Impulse Buying. Journal of Fashion Marketing and Management, 7(3), pp. 282-295.

Donovan, R. J. \& Rossiter. (1982). Store Athmosphere: An Environmental Psychology Approach. Journal of Retailing, Spring.

Fast Retailing. (2014). Industri Ranking. Retrieved from: http://www.fastretailing.com/eng/ir/direction/position.html

Fornell, C., \& Larcker, D.F., (1981). Evaluating structural equation models with unobservable variables and measurement error. Journal of Marketing Research, 18(1), 39-50.

Frontier Consulting Group. (2012). Brand Switching Analysis dalam Industri Ritel Modern. Retrieved: http://www.topbrand-award.com/article/ brand-switching-analysis-dalam-industri-ritelmodern.html

Gluck M. (2009). Why Y Women? UK, USA: Popsugar Media. Sugar Inc. Radar Research.

Han, Y. K., Morgan, G. A., Kotsiopulo, A., \& KangPark, J. (1991). Impulse buying behavior of apparel purchasers. Clothing and Textiles Research Journal, 9(3), 15-21.

Hefer Y. \& Cant M.C. (2013). Visual Merchandising Displays' Effect on Consumers: A Valuable Asset or An Unnecessary Burden for Apparel Retailers.12(10).
Jain, V., Sharma, A., Narwal, P. (2012). Impact of visual merchandising on consumer behavior towards women's apparel. International Journal of Research in Management, 5(2),

Keller, K.L \& Richey K. (2006). The importance of corporate brand personality traits to a successful 21st century business, Brand Management, 14, (1/2). pp. 74-81

Kollat, D. T., \& Willett, R. P. (1967). Customer Impulse Purchasing Behavior. Journal of Marketing Research, 4(1), 21-31.

Kompas.com. (2015). Merek-merek Premium Banjiri Surabaya. Retrieved from:http://properti.kompas.com/index.php/read/2015/01/14/092903621 /Merek-merek.Premium.Banjiri.Surabaya

Landon, E. Laird, Jr. (1974), "Self Concept, Ideal Self Concept, and Consumer Purchase Intentions", Journal of Consumer Research, 1(2), pp. 44-51.

Levy M. \& Weitz B.A. (2007). Retailing Manajement. 6th Edition. Boston: Mc Graw Hill.

Rook, D. W. (1987). The Buying Impulse, Journal of Consumer Research, 14,189-199.

Malhotra, N. K. (2004). Marketing Research: An Applied Orientation. 4th Edition, New Jersey: Pearson Education Inc.

Marketing.co.id (2013). Brand Switching Analysis dalam Industri Ritel Modern. Retrieved from: http://www.marketing.co.id/brand-switchinganalysis-dalam-industri-ritel-modern/

Mehrabian A. and Russell, J.A., (1974). An Approach to Environmental Psychology. in Fisher, Feffrey D., Paul A. Bell, and Andrew Baum (1984). Environmental Psycholog. 2nd ed. New York: Holt, Rinehart and Winston.

Mehta, N. P. \& Chugan, P. K. (2013). The Impact of Visual Merchandising on Impulse Buying Behavior of Consumers: A Case from Central Mall of Ahmedabad India. Universal Journal of Management. 1(2): 76-82.

Nugent R. (2006). Youth in a Global World. Washington: Population Reference Bureau.

Oberman R., Dobbs R., Budiman A., Thompson F., \& Rosse M. (2012). The Archipelago Economy: Unleashing Indonesia's Potential. Jakarta: Mckinsey Global Intitute Indonesia.

Popai/Du Pont. (1977). Point-of-Purchase Institute of the United States of America: Consumer Buying Habits Study Supermarkets, New York.

Rachmawati, Veronica. (2009). Hubungan antara Hedonic Shopping Value, Positive Emotion, dan Perilaku Impulse Buying pada Konsumen ritel. Majalah Ekonomi. XIX(2): 192-209.

Rook, D. W. (1987), The Buying Impulse, Journal of Consumer Research, 14,189-199. 
Rook, D. W., \& Gardner, M. P. (1993). In the mood: impulse buying's affective antecedents. Research in consumer behavior, 6(7), 1-28.

Silalahi U. (2003). Studi Tentang Ilmu Administrasi. Bandung: Sinar Baru Aglesindo.

Simamora, B. (2004). Riset Pemasaran. PT Gramedia Pustaka Utama.

Sood V. (2013). The 5-Star Business Network. New South Wales: Jardin Thomson Ltd Utami, C. W. 2010. Manajemen Ritel: Strategi dan Implementasi Operasional Bisnis Ritel Moderen di Indonesia. Jakarta: Salemba Empat.
Utami, C. W. (2010). Manajemen Ritel: Strategi dan Implementasi Operasional Bisnis Ritel Moderen di Indonesia. Jakarta: Salemba Empat.

Wright, Sewall. (1934). The Method of Path Coefficients. Ann. Math. Statist. 5(3), 161-215.

Yathi D. \& Japarianto E. (2014). Analisis Pengaruh Hedonic Shopping Tendency dan Visual Merchandising terhadap Impulse Buying dengan Positive Emotion sebagai Variabel Intervening pada Area Ladies Matahari Department Store Tunjungan Plaza Surabaya. Jurnal Manajemen Pemasaran. 2(2). 